\title{
Alah bisa karena biasa: Peran perceived behavioral control dalam perilaku memilah sampah di kalangan penjual kantin universitas XYZ
}

\author{
Ashma Nur Afifah \& Ratna Djuwita* \\ Fakultas Psikologi, Universitas Indonesia Depok
}

\begin{abstract}
Abstrak
Penelitian ini bertujuan untuk mengetahui gambaran perilaku memilah sampah dan mengidentifikasi faktor-faktor yang memengaruhinya dalam kerangka Theory of Planned Behavior (TPB). Spesifiknya, kami ingin mengeksplorasi dan menguji faktor apa dari TPB yang berperan pada penjual kantin Universitas XYZ. Studi 1 dilakukan dengan wawancara ke 6 penjual kantin. Hasil eksplorasi kualitatif menemukan bahwa penjual kantin sudah terbiasa memilah sampah. Analisis tematik menemukan bahwa perilaku ini dibentuk dari program wajib dari universitas, penilaian individu terhadap konsekuensi dan tujuan pemilahan (sikap), contoh dan teguran dari pihak yang dianggap penting atau otoritas (norma subjektif), serta kemudahan dalam memilah sampah dengan adanya pengetahuan dan penyediaan fasilitas pemilahan (perceived behavioural control). Studi 2 dilakukan untuk menguji kerangka TPB dan dimensi kepuasan fasilitas pemilahan pada pedagang kantin secara kuantitatif. Kami menyebarkan kuesioner kepada 89 penjual kantin. Hasil analisis regresi ganda menunjukkan bahwa variabel attitude dan norma subjektif secara signifikan berkontribusi $17 \%$ terhadap intensi memilah sampah dan hanya perceived behavioural control yang signifikan berkontribusi sebanyak $21 \%$ terhadap perilaku memilah sampah. Pemilahan yang sudah menjadi kebiasaan menjadi faktor yang diasumsikan menguatkan peran PBC dan meniadakan peran intensi. Peran PBC menjadi penting untuk dapat menjaga perilaku pemilahan sampah di kalangan penjaga kantin Universitas XYZ.
\end{abstract}

Kata kunci: Kebiasaan, Pemilahan Sampah, Penjual Kantin, Perceived Behavioral Control, Theory of Planned behaviour

\begin{abstract}
This study aims to empirically examine the behavior of waste segregation and to explore and test the framework of Theory of Planned Behavior (TPB) among the seller of the canteen at XYZ University. Study 1 was conducted by interviewing 6 canteen sellers. The qualitative results found that canteen sellers were accustomed to waste segregation behavior. Thematic analysis found that this behavior was developed by the waste segregation as mandatory program from university as well as participants' evaluation of consequences and objectives of the program (attitude), examples and reprimands from important parties and authority (subjective norms), easiness on waste sorting by increasing knowledge and providing facilities (perceived behavioral control). Study 2 was conducted to prove the framework of TPB and the satisfaction dimension of sorting facilities in canteen sellers quantitatively by distributing questionnaires to 89 canteen sellers. The results of multiple regression analysis showed that attitude and subjective norm variables significantly contribute $17 \%$ to the intention to sort waste and only perceived behavioral control significantly contributes $21 \%$ to the behavior of sorting waste. We argue that the habit of waste segregation is a factor that strengthen the role of the $\mathrm{PBC}$ and negate the role of intention. The role of $\mathrm{PBC}$ is important to be able to maintain waste segregation behavior among XYZ University canteen guards.
\end{abstract}

Keywords: Canteen Seller, Habits, Perceived Behavioral Control, Theory of Planned behaviour, Waste Segregation Behavior

\section{Pendahuluan}

Pemilahan sampah merupakan salah satu perwujudan pencapaian Sustainable Development
Goals (SDGs). Salah satu indikator yang diukur pada program yang mendukung SDGs adalah pengelolaan sampah dengan adanya program daur ulang, pengolahan limbah dan pengurangan sampah yang 
bisa didaur ulang (Universitas Indonesia, 2018). Terkait dengan hal tersebut, di pertengahan 2018, Universitas XYZ memulai program pemilahan sampah yaitu pemisahan sampah organik, anorganik (yang bisa didaur ulang) dan residu yang akan diangkut dan diolah sesuai dengan jenisnya. Program pemilahan sampah membuat setiap Fakultas di Universitas XYZ wajib untuk memilah sampah tanpa adanya kontaminasi. Kontaminasi di sini adalah tercampurnya sampah yang jenisnya berbeda dalam satu jenis tempat sampah, misal tempat sampah organik yang hanya boleh diisi sampah yang cepat terurai namun tercampur oleh sampah anorganik. Saat sampah masih tercampur, sampah tidak akan diangkut ke TPS (Tarmuji, Komunikasi personal, 22 November, 2018). Untuk mengantisipasi hal ini, setiap Fakultas membangun unit pemilahan sampah dan petugas cleaning service memastikan apakah sampah terpilah dengan baik. Ketika belum, mereka diminta memisahkan sampah sesuai dengan jenisnya (Tarmuji, Komunikasi personal, 22 November, 2018).

Salah satu stakeholder yang harus berpartisipasi dalam pemilahan sampah adalah Penjual yang berada di kantin Fakultas. Kantin merupakan salah satu sumber sampah terbanyak di Perguruan Tinggi. Pada Bulan September 2018, seluruh kantin di Universitas XYZ menghasilkan total $9.440 \mathrm{~kg}$ sampah pada bulan September 2018. Rata-rata per kantin menghasilkan sekitar 377,9 kg sampah per hari (Mulya, Komunikasi personal, 2018, 28 November). Dengan melihat besarnya proporsi sampah organik, dapat disimpulkan perlunya peran penjual kantin fakultas sebagai salah satu stakeholder yang berperan dalam memastikan pemilahan sampah di kantin.

Namun masih jarang ditemukan penelitian untuk mengetahui bagaimana perilaku penjual di kantin terkait dengan pemilahan sampah. Hal ini menjadi penting untuk diketahui mengingat peran penjual kantin sangat strategis dalam menyukseskan program pemilahan kantin Universitas XYZ sehingga penting untuk mengetahui bagaimana perilaku pemilahan sampah penjual kantin selama kebijakan pemilahan diterapkan dan juga faktor yang dapat memengaruhi pemilahan tersebut. Selain itu, menarik untuk diketahui apakah kerangka theory of planned behaviour dari Ajzen (1991) bisa diterapkan pada pedagang kantin Universitas XYZ karena penelitian yang ada pada umumnya menggunakan sampel dari negara Barat, yang budaya maupun tingkat Pendidikan dan pengetahuan juga berbeda. Maka dari itu, studi ini ingin mengetahui gambaran perilaku memilah sampah dan faktor-faktor yang memengaruhinya dalam kerangka Theory of Planned Behavior di kalangan pedagang kantin Universitas XYZ.

\section{Perilaku pemilahan sampah ditinjau dari Theory of Planned Behavior}

Theory of Planned Behavior dari Ajzen (1991) adalah kerangka teori yang banyak dipakai dalam menjelaskan perilaku pro-lingkungan. Teori ini menekankan kepada pentingnya peran personal dan kontekstual dalam mendorong suatu perilaku dan mengapa individu bisa berperilaku yang berbeda di konteks yang berbeda. TPB menekankan pentingnya intensi dalam mendorong agar perilaku dapat terjadi. Intensi diasumsikan sebagai faktor motivasional yang memengaruhi perilaku; menjadi indikasi dari seberapa keras seseorang akan mencoba, seberapa banyak usaha yang akan dikeluarkan untuk berperilaku tertentu (Ajzen, 1991). Ajzen (2011b) menyatakan bahwa intensi bisa berubah dari waktu ke waktu karena ada banyak variabel lain yang memengaruhi intensi. Intensi ini dipengaruhi oleh tiga hal yaitu sikap (attitude), norma subjektif dan perceived behavioural control (PBC).

Sikap adalah Evaluasi seseorang terhadap perilaku (Ajzen, 1991). Sikap ini dipengaruhi oleh keyakinan individu terhadap konsekuensi yang diakibatkan dari perilakunya dan perasaan individu terhadap konsekuensi tersebut (Welcomer, Scherer, Pradenas, Cordano, \& Parada, 2010). Beberapa penelitian menemukan bahwa sikap yang paling memengaruhi intensi untuk memilah (lihat Greaves, Zibarras, \& Stride, 2013; Tonglet, Phillips, \& Bates, 2004). Semakin tinggi sikap positif individu untuk memilah sampah akan semakin tinggi juga intensi untuk memilah sampah sehingga akan diprediksi membuat individu untuk memilah.

Norma subjektif adalah tekanan sosial bagi seseorang untuk berperilaku atau tidak berperilaku (Ajzen, 1991). Menurut Welcomer ,dkk (2010) norma subjektif merupakan persepsi individu terhadap evaluasi dari lingkungan sosial terhadap suatu perilaku dan seberapa jauh individu termotivasi untuk patuh terhadap lingkungan sosial. Ada perbedaan temuan penelitian mengenai pengaruh dari norma sosial terhadap intensi memilah. Miliute-Plepiene, Hage, Plepys, dan Reipas (2016) menyatakan bahwa norma sosial akan memprediksi intensi pada penduduk di negara yang fasilitas pemilahannya belum maju. Dalam konteks itu, masyarakat di negara yang fasilitas pemilahannya belum maju akan lebih terpengaruh dengan ajakan dari tetangganya untuk memulai memilah. Berlawanan dengan penelitian sebelumnya, Mannetti, Pierro, dan Livi (2004) menyatakan bahwa norma sosial baru bisa berjalan saat pemilahan sampah sudah menjadi lumrah dilakukan di lingkungan di tempat individu berada. Disini, masih terdapat inkonsistensi dari penelitian sebelumnya sehingga masih perlu dilakukan penelitian lebih lanjut.

Dimensi terakhir adalah PBC yaitu sumber daya atau kesempatan yang tersedia bagi seseorang untuk memungkinkan perilaku terjadi (Ajzen, 1991). PBC juga merupakan persepsi kontrol secara aktual untuk berperilaku dan dapat memengaruhi perilaku secara langsung. PBC merupakan penilaian personal seseorang terhadap kemampuannya untuk melakukan sesuatu, apakah terdapat kendala langsung maupun tak langsung dalam bentuk fisik yang dapat dipersepsikan sebagai fasilitator atau penghambat suatu perilaku (Zhang, Zhang, Yu, \& Ren, 2016). PBC bisa berupa faktor internal (informasi, kekurangan per- 
sonal, kemampuan, dan emosi) dan faktor eksternal (kesempatan, kebergantungan dengan orang lain dan halangan) (Conner \& Armitage, 1998). Beberapa penelitian membuktikan bahwa PBC merupakan kontributor terbesar dalam intensi dan perilaku memilah (Botetzagias, Dima, \& Malesios, 2015; Greaves , dkk., 2013; Knussen, Yule, MacKenzie, \& Wells, 2004; Mannetti, dkk, 2004). Namun demikian, masih perlu dilakukan riset untuk konteks yang berbeda, salah satunya konteks pemilahan sampah pada pedagang kantin. Ini penting karena perilaku memilah sampah pada konteks pedagang kantin ini bisa jadi dibentuk oleh faktor yang berbeda dari rangkaian faktor-faktor TPB.

Sebuah penelitian yang juga menggunakan kerangka TPB menemukan bahwa selain faktor sikap, norma subjektif dan PBC, kepuasan fasilitas pemilahan yang tersedia juga memengaruhi perilaku pemilahan (Stoeva \& Alriksson, 2017). Mereka membandingkan kondisi pemilahan di Swedia dan Bulgaria di mana di Bulgaria yang dinilai sebagai negara yang fasilitas pemilahannya masih buruk. Hasil penelitian menemukan bahwa kepuasan terhadap pemilahan akan memengaruhi perilaku memilah. Di Swedia yang fasilitas pemilahannya sudah baik, dimensi sikap-lah yang paling memengaruhi perilaku memilah. Stoeva dan Alriksson (2017) menyatakan hal ini disebabkan karena di negara yang fasilitas pemilahannya sudah maju, pemilahan sudah menjadi nilai (value) yang terinternalisasi dengan baik sehingga sikap akan menjadi determinan yang paling besar dalam perilaku memilah.

Pada negara yang fasilitas pemilahannya belum maju, kepuasan terhadap fasilitas akan mendorong masyarakatnya untuk memilah. Ajzen (1991) menyatakan bahwa kerangka teori TPB boleh ditambahkan selama dapat memberikan gambaran lebih utuh pengaruh dari ketiga variabel yang sudah ada terhadap intensi dan perilaku atau yang biasa disebut TPB Extended.

Penulis memilih TPB sebagai kerangka teori untuk memahami perilaku memilah sampah karena TPB adalah pendekatan teoretis yang paling banyak digunakan dan dianggap akan memberikan gambaran serta mengidentifikasi faktor-faktor yang memengaruhi perilaku pemilahan (contoh: Fan, Yang, \& Shen, 2019). Selain itu, TPB merupakan framework yang cukup singkat dalam menentukan determinan dari perilaku (Conner \& Armitage, 1998) dan terbuka untuk ditambahkan variabel penjelas lain agar mampu memberikan penjelasan yang lebih utuh terhadap perilaku (Ajzen, 1991). Penelitian selama ini mengenai kontribusi ketiga dimensi maupun dimensi tambahan tidak menemukan kesimpulan yang konklusif terkait variabel mana yang paling berpengaruh.

Dari studi kepustakaan diketahui telah banyak penelitian yang menggunakan kerangka TPB untuk penelitian dengan tema lingkungan, namun umumnya hanya melibatkan partisipan mahasiswa (Niaura, 2013; Stoeva \& Alriksson, 2017), para ibu rumah tangga (Zhang, dkk 2016) dan karyawan kantor (Greaves , dkk., 2013) dan baru sedikit yang menggali isu lingkungan seperti memilah sampah di kalangan penjual kantin.

Penelitian TPB juga beberapa kali digunakan dengan metode penelitian kualitatif seperti dalam menjelaskan pengambilan keputusan terkait kesehatan (Klobas, 2011; Tan, Hassali, Saleem, Shafie, Aljadhay, \& Gan, 2016) dan konsumsi microbreweries (Carr, Shin, Severt, \& Lewis, 2017). TPB secara kualitatif dilakukan ketika diperlukan dalam memahami kekhasan dari perilaku yang ingin diteliti dalam konteks tertentu serta juga penggalian dari masing-masing aspek TPB itu sendiri (Carr , dkk., 2017; Tan , dkk., 2016). Dari tiga hasil penelitian TPB tersebut, penulis menemukan adanya konsistensi kontribusi ketiga variabel prediktor yaitu sikap, norma subjektif dan PBC dalam memengaruhi perilaku yang ingin diteliti. Misal variabel sikap ditandai dengan adanya evaluasi terhadap manfaat dari perilaku (Tan, dkk., 2016). Teman merupakan aspek dari norma subjektif yang konsisten ditemukan (Carr , dkk., 2017; Renzi \& Klobas, 2008; Tan , dkk., 2016). Pengetahuan dan fasilitas merupakan aspek yang dapat mening-katkan PBC individu dalam melakukan sesuatu (Renzi \& Klobas, 2008; Tan, dkk., 2016). Penulis belum menemukan adanya penelitian kualitatif TPB dalam perilaku memilah sampah, sehingga penting digali juga aspekaspek dalam ketiga variabel TPB ini dalam memengaruhi perilaku memilah sampah.

Penelitian ini dilakukan sebagai baseline study untuk program intervensi yang dapat meningkatkan perilaku memilah sampah. Hal ini menjadi penting diketahui dikarenakan walau disediakannya fasilitas cleaning service yang akan memisahkan di akhir, pemilahan sampah Universitas XYZ akan lebih berhasil saat partisipasi individu, dalam hal ini pedagang kantin juga meningkat, mengingat kantin juga merupakan sumber terbanyak penghasil sampah di Universitas XYZ. Kebijakan ini juga memastikan apakah penjual kantin mengetahui perannya untuk memilah sampah, mengetahui bagaimana cara memilah sampah, mengetahui pentingnya memilah sampah. Oleh karena itu penting untuk menggali faktor-faktor yang dapat menghambat atau mendorong perilaku memilah sampah.

Untuk menggali hal ini, peneliti melakukan dua jenis studi. Studi kualitatif dilakukan untuk lebih memahami konteks dengan menggali gambaran perilaku memilah, informasi yang dipunya mengenai program pemilahan. Juga untuk melakukan identifikasi faktor-faktor yang membentuk perilaku tersebut di kalangan pedagang kantin.

Studi kuantitatif dilakukan untuk menguji faktor dari TPB yang paling berpengaruh terhadap intensi dan perilaku memilah sehingga dapat dijadikan acuan untuk metode intervensi. Studi kualitatif dan kuantitatif dilakukan guna mendapatkan baseline yang komprehensif mengenai perilaku memilah sampah dan juga faktor yang perlu ditingkatkan dalam program intervensi nanti. 


\section{Studi 1: Studi Kualitatif}

\section{Metode Penelitian}

\section{Partisipan, Desain dan Prosedur}

Studi Kualitatif. Studi kualitatif dilakukan untuk memahami konteks, gambaran perilaku memilah sampah, informasi terkait program pemilahan sampah dan juga faktor-faktor yang memengaruhi perilaku memilah sampah. studi 1 ini dilakukan untuk menjawab tiga pertanyaan besar yaitu (1) Bagaimana gambaran perilaku pemilahan sampah di kalangan pedagang kantin Universitas XYZ? (2) Apa saja informasi yang dipunya oleh pedagang kantin Universitas XYZ terkait pemilahan sampah? dan (3) Faktor-faktor apa saja yang memengaruhi perilaku pemilahan sampah di kalangan pedagang kantin Universitas XYZ?

Desain. Studi kualitatif ini dilakukan dengan desain studi kasus. Metode kualitatif dilakukan untuk lebih memahami bagaimana suatu perilaku memilah sampah dapat terbentuk di kalangan penjual Universitas XYZ (Kumar, 2018). Studi kasus merupakan salah satu pendekatan metode kualitatif (lihat Creswell, 2007; Willig, 2008). Metode studi kasus adalah pendekatan dimana peneliti mengeksplorasi sistem yang terbatas (dalam hal ini kasus) dengan menggunakan pengambilan data yang detail, sumber informasi yang banyak dan melaporkan temuannya dalam bentuk deskripsi dan tema yang khas sesuai dengan kasus (Creswell, 2007). Menurut Willig (2008), metode ini cocok digunakan ketika peneliti bermaksud mencari gambaran dan penjelasan terkait fenomena tertentu. Kerangka pertanyaan yang diberikan kepada partisipan disusun menggunakan kerangka teori TPB dari Ajzen ( 2011a).

Partisipan. Peneliti mewawancarai 6 partisipan yang bersedia mengenai proses pemilahan sampah. Terdapat 2 orang perempuan dan 4 orang laki-laki yang bersedia diwawancarai. 4 orang penjual hanya menjual makanan dan 2 orang penjual menjual makanan dan minuman.

Prosedur. Peneliti mendatangi kantin-kantin dan kafe di Fakultas dan meminta kesediaan penjual kantin untuk berpartisipasi dalam penelitian. Wawancara langsung dilakukan di konter penjual. Peneliti mendekati penjual yang sedang tidak terlalu sibuk di konter dan meminta kesediaan waktunya untuk diwawancara. Secara total ada 10 penjual yang peneliti minta kesediaan wawancara, namun dua orang menolak karena tidak berkenan dan dua orang lagi menghentikan wawancara di tengah jalan karena saat itu sedang banyak pembeli. Karena keterbatasan waktu penelitian dan juga waktu yang dipunya oleh target partisipan, Peneliti hanya bisa mewawancarai 6 orang partisipan. Walau begitu, peneliti memastikan bahwa partisipan yang peneliti pilih berasal dari fakultas yang berbeda untuk memperoleh gambaran perilaku pemilahan yang terjadi di fakultas yang berbeda. Wawancara dilakukan dengan pertanyaan yang menggali perilaku memilah individu, pendapat individu mengenai pemilahan sampah, manfaat yang dirasakan mengenai pemilahan sampah, konsekuensi positif dan negatif ketika individu tidak memilah sampah, pihak yang setuju atau tidak setuju terkait perilaku pemilahan sampah, pihak yang dapat memilah sampah secara tepat maupun tidak tepat, siapa yang memotivasi memilah sampah, faktor yang memudahkan dan menyulitkan penjual untuk memilah, pengetahuan mengenai program pemilahan, dan fasilitas yang disediakan dan kepuasan terhadap fasilitas tersebut. Wawancara dilaksanakan dalam setting field di mana penjual biasanya sambil menjaga konternya sehingga terkadang wawancara diselingi oleh proses penjual melayani pembeli. Wawancara pun tidak bisa dilakukan terlalu lama mengingat para penjual masih harus melakukan kewajiban lainnya.

\section{Teknik Analisis dan Hasil Penelitian}

Teknik Analisis. Hasil rekaman wawancara kemudian dibuat verbatim. Panjang verbatim berkisar antara 765 sampai 2.765 kata per orang. Data verbatim lalu diolah melalui proses coding, dengan langkah: pengumpulan hasil pengambilan data, membuat segmentasi kategori-kategori, dan memberi label pada kategori-kategori tersebut (Creswell, 2007). Penulis memberikan coding, lalu meminta seorang expert di bidang TPB untuk mencek ulang coding yang telah dibuat penulis. Proses coding hanya dilakukan oleh peneliti namun peneliti meminta expert yang mengetahui TPB dan untuk mengecek coding yang dilakukan oleh peneliti. Proses coding dilakukan menggunakan landasan teori TPB dengan menambahkan kategori baru yang tidak sesuai dengan frame work teori TPB. Proses coding awal dari verbatim menunjukkan beberapa kategori yang mirip. Kategori yang mirip lalu dikelompokkan ke dalam tema besar kerangka teoritis TPB yang bisa dilihat pada Tabel 1 . Seluruh nama partisipan yang ditampilkan pada hasil wawancara dalam penelitian ini menggunakan nama inisial dari partisipan

Hasil Penelitian. Bagian ini berisi tentang temuan dari hasil wawancara mendalam mengenai pengetahuan para partisipan tentang program pemilahan sampah di universitas XYZ, perilaku memilah sampah, sikap memilah sampah, norma subjektif dalam memilah sampah, dan persepsi kontrol yang dipunya individu terhadap perilaku memilah (PBC).

\section{Pengetahuan Program Pemilahan Sampah}

Seluruh partisipan mengetahui mengenai program pemilahan sampah yang dilakukan oleh Universitas XYZ. Pengetahuan para penjual beragam, ada yang mengenai bagaimana cara memilah sampah sampai dengan detail tata cara pelaksanaan program pemilahan sampah di Universitas XYZ.

"Sekarang wajib memilah, jadi dipisahin antara sampah yang basah dan yang kering" ( $\mathrm{HH}$, Laki-laki, Fakultas Psikologi) 
Tabel 1. Pembagian Kategori dan Tema Coding

\begin{tabular}{|c|c|c|c|}
\hline Contoh Pernyataan & Kategori & Tema & Istilah \\
\hline $\begin{array}{l}\text { "Sekarang wajib memilah, jadi dipisahin } \\
\text { antara sampah yang basah dan yang } \\
\text { kering" }\end{array}$ & $\begin{array}{l}\text { Memilah sampah } \\
\text { wajib dilakukan }\end{array}$ & $\begin{array}{l}\text { Pengetahuan penjual mengenai } \\
\text { program pemilahan sampah }\end{array}$ & $\begin{array}{l}\text { Pengetahuan } \\
\text { Program Pemilahan } \\
\text { Sampah }\end{array}$ \\
\hline $\begin{array}{l}\text { "Biasanya tiap tahun kita dapat sosialisasi } \\
\text { tentang pemilahan sampah dari universitas } \\
\text { atau fakultas kesehatan." }\end{array}$ & $\begin{array}{l}\text { Informasi memilah } \\
\text { didapatkan dari } \\
\text { sosialisasi }\end{array}$ & & \\
\hline $\begin{array}{l}\text { "Kita di counter biasa milah pas buang } \\
\text { sampah.....Tiap buang atau sebelum } \\
\text { pulang, kita biasanya nganterin sampah } \\
\text { dari counter ke deket tempat parkir" }\end{array}$ & $\begin{array}{l}\text { Memilah sampah } \\
\text { sudah biasa } \\
\text { dilakukan }\end{array}$ & $\begin{array}{l}\text { perilaku memilah sampah di } \\
\text { kalangan penjual kantin }\end{array}$ & $\begin{array}{l}\text { Perilaku memilah } \\
\text { sampah (TPB) }\end{array}$ \\
\hline $\begin{array}{l}\text { "Karena aturannya sudah wajib, jadi } \\
\text { biasanya ada teguran dan hukuman kalo } \\
\text { enggak memilah." }\end{array}$ & $\begin{array}{l}\text { Wajib karena ada } \\
\text { aturan }\end{array}$ & $\begin{array}{l}\text { penilaian penjual kantin } \\
\text { terhadap pemilahan sampah }\end{array}$ & $\begin{array}{l}\text { Sikap pemilahan } \\
\text { sampah (TPB) }\end{array}$ \\
\hline $\begin{array}{l}\text { "Bermanfaat buat lingkungan, yang organik } \\
\text { bisa diolah sedangkan anorganik bisa } \\
\text { dibuat jadi barang kembali" }\end{array}$ & $\begin{array}{l}\text { Baik untuk } \\
\text { lingkungan }\end{array}$ & Manfaat pemilahan & \\
\hline $\begin{array}{l}\text { "Kalo kita milah, botol hasil pemilahan bisa } \\
\text { dijual kembali oleh CS, hitung-hitung bantu } \\
\text { lah," }\end{array}$ & Membantu CS & & \\
\hline $\begin{array}{l}\text { "Kita jadi enggak enak kalo enggak milah. } \\
\text { Jadi ngerepotin cleaning service." }\end{array}$ & $\begin{array}{l}\text { Konsekuensi dari } \\
\text { perilaku memilah }\end{array}$ & $\begin{array}{l}\text { Perasaan yang dirasakan penjual } \\
\text { kantin terhadap pemilahan } \\
\text { sampah }\end{array}$ & \\
\hline $\begin{array}{l}\text { "Ya Cleaning service. Kalo sampah ga } \\
\text { dipilah, mereka balikin sampah yang udah } \\
\text { kita buang ke depan pintu konter kita," }\end{array}$ & $\begin{array}{l}\text { Pengaruh Cleaning } \\
\text { Service dalam } \\
\text { memilah sampah }\end{array}$ & $\begin{array}{l}\text { pihak yang memengaruhi } \\
\text { individu untuk memilah sampah. }\end{array}$ & $\begin{array}{l}\text { Norma subjektif } \\
\text { untuk penjual kantin } \\
\text { (TPB) }\end{array}$ \\
\hline $\begin{array}{l}\text { "Kalo di sini penjual lain juga memilah dari } \\
\text { konternya Mbak, ya kita ikutin” }\end{array}$ & $\begin{array}{l}\text { Pengaruh pedagang } \\
\text { kantin lain }\end{array}$ & & \\
\hline $\begin{array}{l}\text { "Kemarin saya lihat sendiri Pak Dekan } \\
\text { milah sampah langsung. Pas ada tong } \\
\text { sampah, dia bongkar lagi sampahnya dan } \\
\text { dia pisah-pisahin sesuai jenis. Kami jadi } \\
\text { tahu kalau memilah itu penting, Pak Dekan } \\
\text { sendiri ngelakuin," }\end{array}$ & $\begin{array}{l}\text { Pengaruh pihak } \\
\text { otoritas dalam } \\
\text { memilah sampah }\end{array}$ & & \\
\hline $\begin{array}{l}\text { “Awalnya kan wajib ya, mau enggak mau } \\
\text { kita lakuin. Tapi lama-lama menjadi biasa. } \\
\text { Gampang malah.” }\end{array}$ & $\begin{array}{l}\text { Perilaku memilah } \\
\text { itu mudah }\end{array}$ & $\begin{array}{l}\text { Persepsi penjual kantin terhadap } \\
\text { control yang dia punya terkait } \\
\text { perilaku memilah sampah yang } \\
\text { dia lakukan }\end{array}$ & $\begin{array}{l}\text { Persepsi kontrol yang } \\
\text { dipunya individu } \\
\text { terhadap perilaku } \\
\text { memilah (PBC) (TPB) }\end{array}$ \\
\hline $\begin{array}{l}\text { "Saya tahu kalo di Universitas XYZ tempat } \\
\text { pembuangan akhir ada di dekat Fakultas } \\
\text { Teknik. Di situ kan sampah basahnya } \\
\text { dijadiin pupuk, jadi kita tahu yang kita } \\
\text { kerjakan ga sia-sia” }\end{array}$ & $\begin{array}{l}\text { Penyediaan } \\
\text { Fasilitas Pemilahan }\end{array}$ & $\begin{array}{l}\text { Fasilitas yang mendorong } \\
\text { perilaku memilah }\end{array}$ & \\
\hline $\begin{array}{l}\text { "yah kayaknya puas-puas aja, enggak perlu } \\
\text { disediain apa-apa lagi. Enggak usah dikasih } \\
\text { tempat sampah dalam konter nanti } \\
\text { sempit." }\end{array}$ & $\begin{array}{l}\text { Kepuasan terhadap } \\
\text { fasilitas pemilahan }\end{array}$ & & \\
\hline $\begin{array}{l}\text { "Rutin ada sosialisasi tiap tahun dari } \\
\text { Fakultas kesehatan. Kita jadi tahu apa yang } \\
\text { harus dilakukan. Lagipula kan jadi tahu tuh } \\
\text { manfaatnya pemilahan." }\end{array}$ & $\begin{array}{l}\text { Sosialisasi untuk } \\
\text { meningkatkan } \\
\text { pengetahuan }\end{array}$ & $\begin{array}{l}\text { Sosialisasi sebagai faktor dalam } \\
\text { meningkatkan pememilahan } \\
\text { sampah }\end{array}$ & \\
\hline
\end{tabular}

"Universitas XYZ sudah melakukan pemilahan sampah dimana sampah basah akan dijadikan kompos. Sampah basah itu seperti sisa makanan, sayuran, telur, kulit telur dan lainnya bakal diolah lagi di tempat dekat XYZ buat jadi kompos." (AY, Laki-laki, Fakultas Hukum)
"Pemilahan sampah itu sangat baik, karena dapat mempermudah memilah-milah sampah seperti botol, makanan dan minuman. Karena kalau tidak memilah sangat buruk bagi sampah-sampah yang mau didaur ulang, nanti harga jualnya jadi jatuh. Yang saya tahu kan 
sampah basahnya akan diangkut oleh Tim Sampah Universitas dan yang daur ulang di jual ke bank sampah." (DW, Laki-laki, Fakultas Psikologi)

"Wajib dilakukan. Makanya disediakan tong sampah di dekat kantin sesuai dengan jenisnya, biasanya sih sampah organik dan nonorganik, nanti dari tong sampah ini katanya dibawa ke tempat pengolahan sampah" (M, Perempuan, FIB)

Aspek informasi mengenai program pemilahan sampah dari enam partisipan yang dapat diwawancara menunjukkan paling tidak mereka mengetahui Universitas XYZ telah melakukan program pemilahan sampah. Sosialisasi menjadi cara penyebaran pengetahuan bagi penjual kantin yang dilakukan oleh pihak universitas, fakultas maupun dari pihak cleaning service sendiri yang memang menangani soal sampah.

"counter kantin di FE wajib melakukan pemilahan sampah, di tiap counter biasanya menyediakan kantong sendiri untuk pemilahan. Biasanya tiap tahun kita dapat sosialisasi tentang pemilahan sampah dari universitas atau fakultas kesehatan." (A, Laki-laki, FE)

"Biasanya CS akan ngingetin kalo ada yang masih kecampur, kita disuruh misahin lagi. Pengangkutan sampah dengan ember diangkut ke kendaraan sampah, tapi enggak tahu dibawa ke mana, katanya dijadiin kompos gitu." (S, Perempuan, FT)

\section{Perilaku memilah sampah}

"Kita di counter biasa milah pas buang sampah. Biasanya kita sediain dua tempat sampah, satu buat yang basah dan satu lagi buat yang kering. Tiap buang atau sebelum pulang, kita biasanya nganterin sampah dari counter ke deket tempat parkir (tempat pemilahan sampah di Fakultas tersebut, red.). Besok baru deh dipilah lagi sama CS."(AY, Laki-laki, FH)

"Di dekat wastafel, Pihak CS menyediakan bak sampah ada 3 jenis yaitu bak untuk sampah basah, bak sampah untuk sampah kering dan bak sampah untuk residu. Di masing-masing counter, kita menyediakan sendiri plastik sesuai dengan jenis bak yang ada untuk buang sampah dalam counter. Tiap masak, bikin jus atau sisa makanan kita buang di plastik yang basah. Kalo sendok-sendok plastik kita buang di tempat yang kering. Kalo di counter udah penuh (plastik tempat sampah red.), biasanya sore, kita buang di bak itu, nanti akan ada CS yang mengangkut bak itu tiap sore" (DW, Lakilaki, F. Psikologi).

"Nanti di masing-masing counter, kita sudah menyediakan plastik untuk memisahkan sampah. Biasanya plastiknya sih bekas dari belanja sayur. Pas nyiangin sayur kalo ada sisa sayuran, kita masukin ke tempat sampah basah. Pas pulang atau saat tempat sampah sudah penuh, nanti kita buang ke bak sampah di belakang kantin. Tapi sebenarnya sampah anorganik juga jarang sih kalo dari counter, paling kalo ada kita buang ke tempat sampah di luar counter. Kita udah biasa sih, soalnya gampang" (S, Perempuan, FT).

Dari hasil wawancara dapat terlihat memilah sampah sudah menjadi kebiasaan bagi penjual kantin mulai dari di counter tempat mereka berjualan. Mereka berusaha memisahkan sampah ketika membuang sampah di tempat sampah dalam counter-nya. Mereka menyesuaikan dengan jenis sampah yang ditentukan oleh cleaning service setiap Fakultas. Ada yang memisahkan dua jenis yaitu organik maupun anorganik, ada yang memisahkan sebanyak tiga jenis. Mereka lalu membuang sampah di tempat yang sudah ditentukan tiap harinya. Dalam kerangka theory of planned behavior, semakin sering suatu perilaku dilakukan dalam konteks yang stabil, semakin perilaku tersebut menjadi kebiasaan dan berada dalam pengaruh dari tanda stimulus eksternal yang melemahkan peran intensi (Ajzen, 2011b).

\section{Sikap Memilah Sampah}

"Kita tahu memilah itu wajib karena ada aturannya. Kita biasanya ada sosialisasi mbak tiap tahunnya terkait sampah, jadinya kita tahu kalo milah itu wajib," (S, Perempuan, FT)

"Karena aturannya sudah wajib, jadi biasanya ada teguran dan hukuman kalo enggak memilah. Hal ini efektif buat penjual jadi patuh." (M, Perempuan, FIB)

Aturan yang wajib mengenai pemilahan sampah membuat penjual merasa pemilahan sampah menjadi patuh untuk melakukan pemilahan. Karena hal ini wajib maka dirasa perilaku ini memang penting untuk dilakukan. Adanya aturan yang jelas mengenai kewajiban memilah memengaruhi keyakinan individu terhadap perilaku memilah sampah bahwa hal tersebut adalah penting (Ajzen \& Fishbein, 1972).

Selain nilai, konsekuensi dari perilaku juga merupakan komponen dalam dimensi sikap (Ajzen, 1991). Semua penjual kantin berpendapat positif mengenai pemilahan sampah. Mereka menyebutkan memilah sampah bermanfaat untuk lingkungan.

"Bermanfaat buat lingkungan, yang organik bisa diolah sedangkan anorganik bisa dibuat jadi barang kembali" (DW, Laki-laki, Fakultas Psikologi).

"Baik untuk lingkungan karena dapat turut menjaga lingkungan” (HH, Laki-laki, Fakultas Psikologi).

Selain menjaga lingkungan, alasan prososial juga keluar dari hasil wawancara dengan responden. Banyak yang merasa dengan memilah, mereka mem- 
bantu beberapa pihak yang terlibat dalam pemilahan sampah.

"Hal yang membantu CS menambah pemasukan. Jadi CS tidak perlu memisahkan kembali sampah-sampah itu, terus langsung bisa dibuang sesuai dengan jenis" (A, Laki-laki Penjual kantin FE).

"Kalo kita milah, botol hasil pemilahan bisa dijual kembali oleh CS, hitung-hitung bantu lah," (S, Perempuan, FT).

Bantuan terhadap pemasukan cleaning service menjadi alasan bagi beberapa penjual kantin untuk membantu pemilahan sampah. Mereka menyadari bahwa hasil pemilahan ini akan dijual kembali oleh para cleaning service untuk menambah pemasukan dan mereka bersedia untuk membantu. Kepercayaan bahwa memilah akan membawa akibat baik bagi lingkungan atau manfaat baik untuk petugas cleaning service merupakan keyakinan (belief) individu akan konsekuensi dari perilaku tersebut dan memengaruhi sikap individu. Menurut Welcomer, dkk (2010) komponen sikap adalah keyakinan individu akan konsekuensi dari perbuatannya dan termasuk di dalamnya konsekuensi afektif yang dirasakan individu.

Konsekuensi afektif yang dirasakan individu adalah rasa sungkan terhadap cleaning service ketika tidak melakukan perilaku tersebut.

"Kita jadi enggak enak kalo enggak milah. Jadi ngerepotin cleaning service. Apalagi kalo fakultasnya kecil, kita kan jadi kenal satu dengan yang lain. Jadi dia pasti tahu kalo saya enggak milah," (DW, Laki-laki, Fakultas Psikologi).

Selain itu ada konsekuensi afektif negatif lain juga ditentukan terkait dengan kesulitan yang dihadapi dalam pemilahan sampah. Hal ini terjadi saat partisipan terburu-buru membuang sampah karena banyaknya pembeli atau penjual diwajibkan untuk menyediakan dua tempat sampah,

"Kadang kita enggak teliti pas buang sampah. Sulit saat pelanggan lagi banyak membeli, kadang terburu-buru membuang sampah tidak lihat dulu jenisnya," (S, Perempuan, FT)

"Jadi sulit ketika kita wajib ada dua tempat sampah. Konter itu sempit mbak, bisa-bisa saya enggak bisa gerak kalo ada dua tempat sampah. Untungnya sekarang pakai plastik aja boleh,"(A, Laki-laki, FE)

\section{Norma subjektif yang memengaruhi pemilahan sampah}

Norma subjektif adalah persepsi individu terhadap tekanan sosial dalam berperilaku sesuai dengan yang lingkungan sosial harapkan (Ajzen, 1991). Beberapa pihak yang diidentifikasi sebagai pihak sosial yang bisa menekan perilaku memilah sampah adalah cleaning service sebagai pihak pertama yang menangani sampah secara kecil.

"Ya cleaning service. Kalo sampah ga dipilah, mereka balikin sampah yang udah kita buang ke depan pintu konter kita," (AY, Laki-laki, Fakultas Hukum)

"Cleaning service biasanya negur saat sampah engga dipilah. Kayak yang saya bilang tadi, Fakultas ini kecil ya, kita udah saling kenal satu dengan yang lain, ya enggak enak lah kalo sampai ditegur," (DW, Laki-laki, Fakultas Psikologi)

"Teman-teman CS karena mereka akan menegur ketika ada sampah yang tidak tepat dipilah, mereka biasanya protes ke kita karena mereka jadi sibuk misah-misahin sampah," (A, Laki-laki, FE)

Dari pernyataan di atas dapat terlihat bahwa penjual kantin mempunyai motivasi yang tinggi untuk patuh terhadap cleaning service. Menghindari teguran dari cleaning service menjadi motivasi bagi penjual kantin untuk rajin melakukan pemilahan sampah. Selain cleaning service, peran penjual lain juga menjadi penting. Partisipan mengaku bahwa mereka melihat bagaimana penjual lain juga memilah sehingga mereka akan mengikuti hal tersebut.

“Teman-teman penjual lain juga menyediakan dua jenis kantong sampah di konternya. Kita ikutan soalnya malu kalo enggak"

(S, Perempuan, FT)

"Kalo di sini penjual lain juga memilah dari konternya Mbak, ya kita ikutin"

(M, Perempuan, FIB)

Peran pihak yang dianggap otoritas seperti pengawas kantin atau pihak dekanat juga besar untuk menekankan pentingnya pemilahan sampah. Mereka dianggap dapat memberikan panutan yang benar kepada para penjual kantin dan menekankan urgensi bahwa pemilahan sampah merupakan hal yang harus dilakukan. Motivasi untuk mematuhi pihak otoritas ini cukup tinggi di kalangan penjual kantin.

"Kemarin saya lihat sendiri Pak Dekan milah sampah langsung. Pas ada tong sampah, dia bongkar lagi sampahnya dan dia pisah-pisahin sesuai jenis. Kami jadi tahu kalau memilah itu penting, Pak Dekan sendiri ngelakuin," (S, Perempuan, FT)

"Bu Wadek (wakil dekan, red.) sering ngecek ke kantin. Pernah ada penjual yang dimarahi sama Bu Wadek karena sampahnya belum dipilah." (M, Perempuan, FIB)

"Kalo ada konter yang bandel enggak mau memilah sampah, biasanya CS akan ngadu ke bagian ventura Fakultas. Nanti konter itu akan ditegur." (A, Laki-laki, FE) 


\section{Persepsi kontrol yang dipunya individu terhadap perilaku memilah (PBC)}

Mayoritas menganggap pemilahan sampah adalah hal yang wajib mereka lakukan. Kewajiban ini membuat mereka menjadi terbiasa untuk memilah sampah. Karena sudah terbiasa mereka menjadi menganggap perilaku tersebut mudah dilakukan.

"Awalnya kan wajib ya, mau enggak mau kita lakuin. Tapi lama-lama menjadi biasa. Gampang malah. Kita bisa pakai kantong sampah bekas belanja sayur sebagai tempat sampah basah." (S, Perempuan, Fakultas Teknik).

Hal ini menunjukkan perceived behavioral control yaitu keyakinan individu bahwa dirinya bisa dan mempunyai kontrol untuk memilah sampah (Greaves , dkk., 2013). Dalam hal ini, partisipan merasa memilah sampah itu mudah dan hal ini membuat dirinya bisa melakukan pemilahan sampah. Bahkan individu menemukan cara untuk lebih memudahkan memilah sampah dengan memanfaatkan plastik bekas belanja sayur.

Hal lain yang dapat membantu individu meningkatkan keyakinan individu untuk memilah sampah adalah fasilitas. Fasilitas di sini bukan hanya menyediakan tempat sampah pemilahan, tetapi adanya fasilitas yang bisa dilihat penjual bahwa benar memang sampah akan dipilah oleh cleaning service (Zhang, dkk, 2016) . Hal ini membuat penjual merasa perilaku memilah mereka tidak sia-sia

"Kita tahu memang di tempat pembuangan sampah terpusat di Fakultas tempat para CS memilah sampah, jadi ya emang bener kalo sampah harus dipisah-pisah sesuai jenis." (AY, Laki-laki, FH)

"Saya tahu kalo di Universitas XYZ tempat pembuangan akhir ada di dekat Fakultas Teknik. Di situ kan sampah basahnya dijadiin pupuk, jadi kita tahu yang kita kerjakan ga siasia" (A, Laki-laki, FE)

"Bak sampah dengan jenis yang berbeda (organik, anorganik dan residu) di dekat wastafel sebagai tempat pembuangan sampah sementara di kantin Psikologi. Pas lihat ada bak sampah tiga jenis untuk memilah saya jadi tahu kalo emang ini harus dipilah," (HH, Lakilaki, Fakultas Psikologi).

Adanya fasilitas pemilahan sampah sangatlah penting dalam proses pemilahan sampah (Greaves , dkk., 2013). Zhang, dkk (2016) menyatakan bahwa akses terhadap fasilitas, di satu sisi menunjukkan kendala tak langsung dan secara langsung menunjukkan realisasi dari perilaku. Selain itu peraturan yang jelas tentang memilah dilengkapi dengan konsekuensi yang konsisten membantu penjual kantin dalam proses membiasakan diri untuk memilah. Walau Stoeva dan Alriksson (2017) menyatakan kepuasan terhadap fasilitas pemilahan berpengaruh terhadap perilaku pemilahan sampah di negara yang mempunyai sistem pemilahan sampah yang buruk. Dalam hal ini tidak ditemukan adanya evaluasi terhadap fasilitas pemilahan sampah dari partisipan. Empat dari enam penjual menjawab tidak ada ketika ditanyakan mengenai fasilitas yang harus disediakan berkaitan dengan pemilahan. Dua orang lainnya meminta terkait dengan kehadiran tempat sampah.

"yah kayaknya puas-puas aja, enggak perlu disediain apa-apa lagi. Enggak usah dikasih tempat sampah dalam konter nanti sempit. Toh kita bisa pakai plastik hasil dari belanja," (S, Perempuan, Fakultas Teknik)

"Selama ini kita nyediain tempat sampah atau plastik sendiri. Kalo dikasih tempat sampah atau plastik memilah di konter, kayaknya lebih asyik" (AY, Laki-laki, Penjual FH)

"Tempat sampah di pembuangan akhir di kantin harus disediakan setiap saat, kalo bisa ada penggantinya saat diangkut ke tempat pembuangan sampah akhir." (DW, Laki-laki, Penjual Psikologi)

Selain itu sosialisasi tentang pemilahan sampah juga membantu meningkatkan pengetahuan individu terkait dengan perilaku memilah sampah.

"Tiap tahun biasanya kita diundang sosialisasi, mau dari universitas maupun fakultas kesehatan. Di situ diterangin apa itu sampah organik, apa itu anorganik, gimana cara buangnya, jadi sekarang kita udah hafal." (S, Perempuan, Penjual FT)

"Rutin ada sosialisasi tiap tahun dari Fakultas kesehatan. Kita jadi tahu apa yang harus dilakukan. Lagi pula kan jadi tahu tuh manfaatnya pemilahan." (A, Laki-laki Penjual kantin FE).

Sosialisasi yang dilakukan meningkatkan pengetahuan individu dalam memilah dan hal ini dapat memengaruhi kontrol individu terhadap kemampuan dirinya untuk memilah.

\section{Diskusi}

Berdasarkan hasil studi kualitatif ditemukan bahwa penjual kantin Universitas XYZ telah mengetahui adanya program pemilahan sampah. Dengan adanya program dari Universitas XYZ, mereka merasa memilah sampah merupakan hal yang wajib dilakukan. Adanya program ini juga membuat perilaku memilah sampah menjadi hal yang biasa diakukan di kalangan penjual kantin Universitas XYZ terutama saat mereka membuat makanan di konter.

Sama seperti temuan studi kualitatif sebelumnya (lihat Carr, dkk., 2017; Klobas, 2011; Tan, dkk., 2016), variabel TPB juga teridentifikasi pada temuan studi ini. Variabel sikap dipengaruhi oleh adanya perasaan wajib memilah sampah yang timbul akibat 
adanya aturan. Selain itu, variabel sikap juga dipengaruhi oleh evaluasi penjual kantin terhadap manfaat pemilahan sampah bagi lingkungan serta rasa tidak enak ketika mereka tidak melakukan pemilahan. Selain sikap, faktor norma subjektif juga ditemukan. Cleaning service merupakan pihak yang efektif dalam mengingatkan pedagang saat mereka masih ada yang salah memilah sampah.

Contoh dari pedagang lain dan juga pihak yang dianggap otoritas di Fakultas seperti Dekan, Wakil Dekan dan pihak ventura Fakultas juga memengaruhi norma subjektif penjual kantin dan menganggap bahwa orang-orang di sekitarnya menyetujui pemilahan sampah. Variabel lain yang teridentifikasi dari TPB adalah PBC dimana persepsi individu akan kontrol yang dipunya memengaruhi intensi dan perilaku memilah. Persepsi individu bahwa memilah sampah itu mudah membuat penjual kantin tetap melakukan pemilahan sampah. Persepsi ini membuat penjual menyiapkan strategi sendiri dalam memilah sampah di konter, seperti menggunakan plastik bekas belanja sayur sebagai wadah tempat pemilahan di konter.

Adanya fasilitas terkait pemilahan sampah, rasa puas terhadap fasilitas tersebut dan juga adanya sosialisasi yang dilakukan dalam meningkatkan pengetahuan mengenai bagaimana cara memilah sampah menjadi faktor-faktor yang ditemukan memengaruhi variabel PBC. Setelah variabel TPB ini teridentifikasi, penulis ingin mengetahui kontribusi dari masing-masing faktor dalam menentukan aspek yang ingin diintervensi dalam perilaku memilah sampah

\section{Studi 2: Studi Kuantitatif}

\section{Metode Penelitian}

\section{Partisipan, Desain dan Prosedur}

Dari studi kualitatif ditemukan perilaku memilah sampah sudah dilakukan oleh penjual kantin Universitas XYZ dan juga ditemukan adanya beberapa tema yang dapat diwakili dalam variabel TPB. Setelah diketahui bahwa pemilahan sampah sudah berjalan dengan baik, penulis ingin mengidentifikasi seberapa besar kontribusi dari masing-masing dimensi TPB terhadap perilaku pemilahan sampah di kalangan penjual kantin Universitas XYZ dalam studi kuantitatif.

Selain variabel dari kerangka teori TPB ini, peneliti juga memasukkan variabel kepuasan terhadap fasilitas pemilahan, mengingat Universitas XYZ telah menyediakan beberapa fasilitas dalam rangka pemilahan. Pengukuran variabel kepuasan ini penting karena penulis ingin mengetahui apakah pada pedagang kantin universitas XYZ kepuasan terhadap fasilitas pemilahan memengaruhi intensi dan perilaku memilah sampah. Ada dua hipotesis yang diajukan dalam penelitian ini: $\mathrm{H} 1$ dan $\mathrm{H} 2$. H1: sikap, norma subjektif, PBC dan kepuasan terhadap fasilitas pemilahan akan memprediksi intensi memilah sampah. H2: Intensi, PBC dan kepuasan terhadap fasilitas pemilahan akan memprediksi intensi perilaku memilah sampah.

Desain. Penelitian ini dilakukan dengan menggunakan metode kuantitatif, cross sectional study dan non-eksperimen. Metode kuantitatif dilakukan untuk menggeneralisasi temuan terhadap populasi (Kumar, 2018). Metode kuantitatif cross-sectional study dilakukan dengan mengambil data menggunakan kuesioner self-report dan menggunakan kerangka TPB dari Zhang dkk (2016) yang mengukur sikap, norma subjektif, perceived behavioural control, intensi dan perilaku memilah sampah. Ditambah juga dengan kepuasan terhadap fasilitas pemilahan sampah dari Stoeva dan Alriksson (2017) yang diadaptasi dalam Bahasa Indonesia. Peneliti tidak memberikan manipulasi apapun kepada partisipan dalam penelitian ini. Alat ini peneliti uji cobakan dulu kepada 32 penjual kantin untuk menguji keterbacaan serta validitas dan reliabilitas. Berikut hasil uji coba validitas dan reliabilitas.

Hasil reliabilitas menunjukkan hasil yang baik menurut Kaplan dan Sacuzzo (2009) namun hasil validitas item pada variabel sikap, norma subjektif dan PBC masih kurang baik berdasarkan standar dari Urbina (2004). Penulis memutuskan untuk tidak mengurangi item namun merevisi item yang kurang dimengerti bagi responden.

Partisipan. Data kuantitatif didapatkan dari yang bekerja sebagai penjual makanan di kantin atau pemilik kios atau counter yang berjualan makanan dan minuman di Universitas XYZ. Partisipan yang mengikuti penelitian ini merupakan pedagang kantin dari 9 Fakultas yang berbeda. Dari 91 partisipan yang bersedia mengisi kuesioner, dua data partisipan harus dikeluarkan dari pengolahan data karena respon yang diberikan di semua pertanyaan sama, sehingga dikhawatirkan partisipan tidak mengisi kuesioner dengan seksama. Jumlah 89 ini dirasa cukup dipakai dalam menganalisis data mengingat jumlah pedagang kantin di setiap Fakultas tidak sama dan tidak semua pedagang kantin bersedia untuk berpartisipasi dalam penelitian. Partisipan terdiri dari 50 laki-laki dan 39 perempuan. Usia penjual berada di antara 18-72 tahun dengan rata-rata usia $(M)=37,28$ tahun dan SD $=14,1$. Pendidikan partisipan bervariasi antara SD $(9,5 \%)$, SMP $(26,3 \%)$, SMA $(54,4 \%)$ dan S1 $(6,7 \%)$. Penjual tersebar ke 9 Fakultas yang ada di Universitas $\mathrm{XYZ}$.

Prosedur. Data didapatkan penulis dengan cara mendatangi kantin-kantin dan kafe di beberapa Fakultas universitas XYZ, dan meminta kesediaan penjual kantin untuk berpartisipasi dalam penelitian. Sebelum pengisian kuesioner, peneliti menjelaskan tujuan dari penelitian dan waktu yang dibutuhkan untuk pengisian kuesioner. Saat partisipan setuju, maka peneliti akan memberikan lembaran informed consent untuk ditandatangani dan setelah itu kuesioner untuk diisi. Mayoritas dari kuesioner disebar pagi hari sekitar jam 08.00-11.00 WIB. Kuesioner tersebut 
Tabel 2. Hasil Uji Coba Validitas dan Reliabilitas

\begin{tabular}{|c|c|c|c|c|}
\hline No & Skala Pengukuran & $\begin{array}{l}\text { Jumlah } \\
\text { Item }\end{array}$ & Reliabilitas $(\alpha)$ & Validitas \\
\hline 1 & Sikap (Zhang et al., 2016) & 4 & 0,55 & $0,12-0,57$ \\
\hline 2 & $\begin{array}{l}\text { Norma subjektif (Zhang et al., } \\
\text { 2016) }\end{array}$ & 5 & 0,64 & $0,16-0,57$ \\
\hline 3 & PBC (Zhang et al., 2016) & 6 & 0,74 & $0,08-0,83$ \\
\hline 4 & $\begin{array}{l}\text { Intensi Memilah Sampah } \\
\text { (Zhang et al., 2016) }\end{array}$ & 3 & 0,76 & $0,52-0,75$ \\
\hline 5 & $\begin{array}{l}\text { Perilaku Memilah Sampah } \\
\text { (Zhang et al., 2016) }\end{array}$ & 6 & 0,54 & $0,36-0,45$ \\
\hline 6 & $\begin{array}{l}\text { Kepuasan terhadap program } \\
\text { pemilahan (Stoeva \& } \\
\text { Alriksson, 2017) }\end{array}$ & 4 & 0,79 & $0,44-0,83$ \\
\hline
\end{tabular}

Tabel 3. Hasil Validitas dan Reliabilitas Alat Ukur Penelitian

\begin{tabular}{clccc}
\hline No & Skala Pengukuran & $\begin{array}{c}\text { Jumlah } \\
\text { Item }\end{array}$ & Reliabilitas $(\alpha)$ & Validitas \\
\hline 1 & Sikap (Zhang et al., 2016) & 4 & 0,61 & $0,2-0,61$ \\
2 & $\begin{array}{l}\text { Norma subjektif (Zhang et al., } \\
\text { 2016) }\end{array}$ & 5 & 0,86 & $0,54-0,61$ \\
3 & PBC (Zhang et al., 2016) & 6 & 0,78 & $0,26-0,76$ \\
4 & $\begin{array}{l}\text { Intensi Memilah Sampah } \\
\text { (Zhang et al., 2016) Sampah }\end{array}$ & 3 & 0,65 & $0,26-0,76$ \\
5 & $\begin{array}{l}\text { Perilaku Memilah } \\
\text { (Zhang et al., 2016) pram }\end{array}$ & 4 & 0,62 & $0,39-0,49$ \\
6 & $\begin{array}{l}\text { Kepuasan terhadap program } \\
\text { pemilahan (Stoeva \& } \\
\text { Alriksson, 2017) }\end{array}$ & & 0,77 & $0,52-0,64$ \\
\hline
\end{tabular}

peneliti tinggal pada partisipan untuk kemudian diambil kembali di sore hari atau keesokan harinya. Untuk penjual yang sudah berumur, peneliti membacakan pertanyaan dan pilihan jawaban lalu mengisikannya jawaban yang disebutkan ke dalam kuesioner.

Pengukuran. Kuesioner TPB yang digunakan menggunakan skala likert dengan 6 skala point; poin 1 menunjukkan sangat tidak setuju dan poin 6 menunjukkan sangat setuju. Dari analisis validitas (internal consistency) dan reliabilitas (cronbach alpha), penulis berpendapat bahwa alat ukur yang digunakan memiliki validitas dan reliabilitas yang bagus.

\section{Teknik Analisis dan Hasil Penelitian}

Teknik Analisis. Untuk respon pada kuesioner, jawaban dari partisipan diubah ke dalam bentuk skor, item yang menanyakan konstruk yang sama dijumlahkan dan dilakukan mean centering. Peneliti melakukan regresi ganda dari sikap, norma subjektif, dan PBC dan persepsi terhadap program dan fasilitas pemilahan sampah terhadap intensi untuk memilah.
Kemudian peneliti juga melakukan regresi ganda dari intensi untuk memilah, PBC dan persepsi terhadap program dan fasilitas pemilahan sampah terhadap perilaku memilah sampah.

Temuan Preliminary. Hasil korelasi bivariat menunjukkan hanya norma subjektif $\operatorname{r}(89)=0,30$, $\mathrm{p}<0,95)$ dan kepuasan terhadap fasilitas $(\mathrm{r}(89)=0,30$, $\mathrm{p}<0,95)$ yang signifikan berhubungan dengan intensi sedangkan sikap $(r(89)=0,52, p<0,99)$, norma subjektif $(r(89)=0,39 \mathrm{p}<0,99)$ dan PBC $(r(89)=0,46$, $\mathrm{p}<0,99)$ secara signifikan berhubungan dengan perilaku memilah sampah (dapat dilihat di Tabel 4).

\section{Perilaku Memilah di Kalangan Pedagang Kantin Universitas XYZ dengan kerangka TPB}

Dari hasil regresi ganda diketahui bahwa hanya sikap dan norma subjektif secara signifikan memengaruhi intensi membuang sampah, namun ternyata perceived behavioural control dan persepsi terhadap program pemilahan sampah tidak signifikan memengaruhi intensi sehingga hipotesis 1 tidak terbukti 
Tabel 4. Analisis Korelasi antara Variabel Penelitian

\begin{tabular}{|c|c|c|c|c|c|c|c|c|c|c|}
\hline & $\mathrm{M}$ & SD & 1 & 2 & 3 & 4 & 5 & 6 & 7 & 8 \\
\hline 1.Sikap & 19,49 & 3,09 & - & $0,27 *$ & 0,21 & $-0,08$ & $-0,16$ & $0,52^{* *}$ & $-0,04$ & $-0,06$ \\
\hline 2.Norma Subjektif & 23,02 & 4,62 & & - & $0,41^{*}$ & 0,17 & $0,30 * *$ & $0,39 * *$ & $0,22^{*}$ & 0,03 \\
\hline 3. $\mathrm{PBC}$ & 29,65 & 3,42 & & & - & $0,43^{* *}$ & 0,17 & $0,46^{* *}$ & 0,21 & 0,14 \\
\hline $\begin{array}{l}\text { 4.Kepuasan Terhadap } \\
\text { Fasilitas }\end{array}$ & 18,64 & 3,09 & & & & - & $0,24 *$ & 0,18 & 0,18 & $0,27^{*}$ \\
\hline 5. Intensi & 12,92 & 3,09 & & & & & - & 0,09 & 0,11 & 0,04 \\
\hline 6. Perilaku Memilah & 14,17 & 2,47 & & & & & & - & 0,02 & 0,04 \\
\hline 7. Usia & 37,28 & 14,10 & & & & & & & - & $0,29 *$ \\
\hline 8. Jenis Kelamin & 0,44 & 0,49 & & & & & & & & - \\
\hline
\end{tabular}

Catatan: *signifikan pada level of confidence 95\%;

${ }^{* *}$ signifikan pada level of confidence $99 \%$
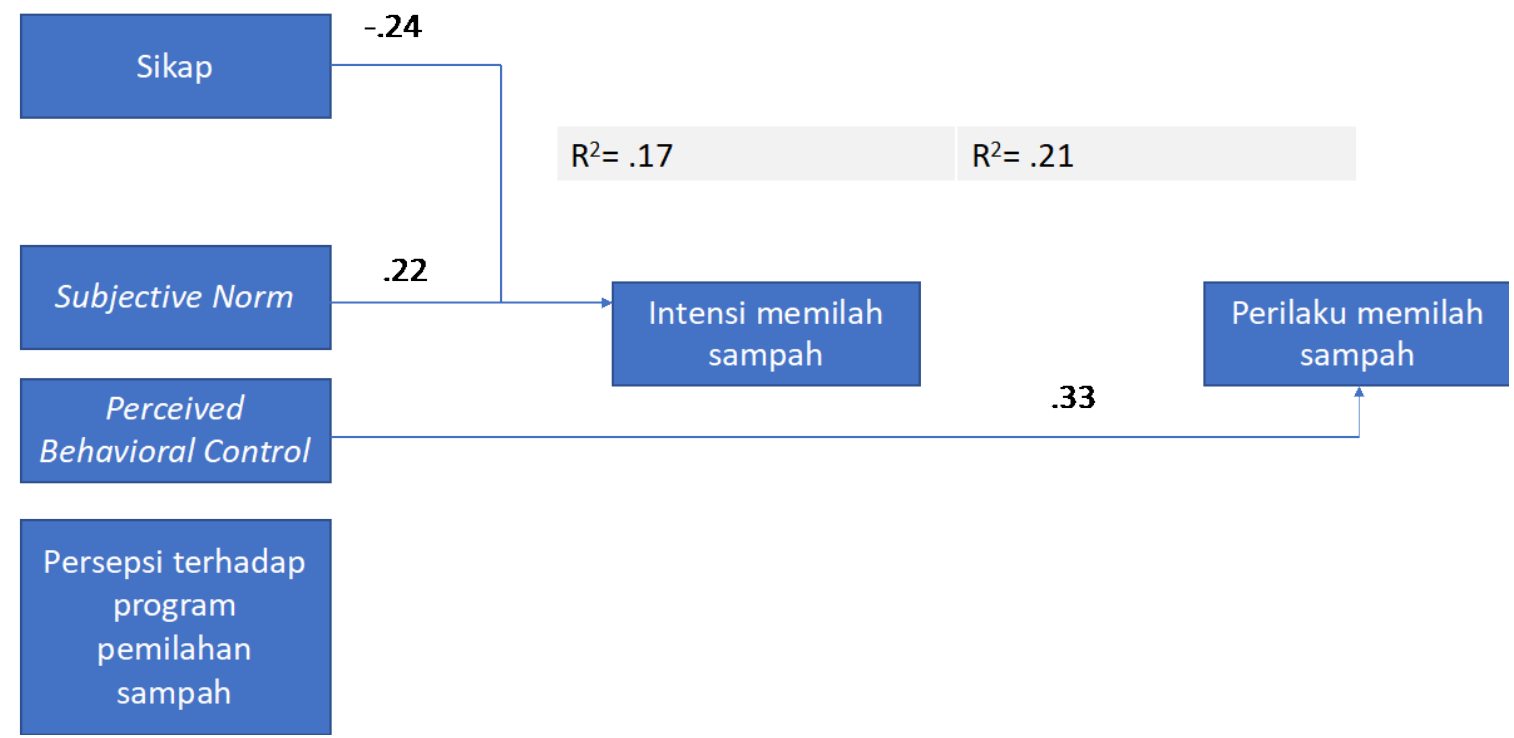

Gambar 1. Bagan hasil regresi perilaku memilah sampah menggunakan kerangka theory of planned behavior

Hasil pada Tabel 5 juga menunjukkan bahwa sikap mempunyai kontribusi negatif terhadap intensi memilah sampah. Artinya semakin positif sikap individu terhadap pemilahan sampah, semakin rendah intensi dirinya untuk membuang sampah dan begitu pula sebaliknya. Kontribusi terhadap intensi paling besar berasal dari norma subjektif.

Berbeda dengan kerangka theory of planned behaviour, regresi ganda pada perilaku memilah sampah menunjukkan bahwa hanya perceived behavioural control yang memengaruhi perilaku memilah sampah di kalangan penjual kantin Universitas XYZ.

Dari gambar 1 dapat disimpulkan bahwa hanya PBC yang memengaruhi perilaku memilah sampah dan menjelaskan $21 \%$ variansi dari perilaku memilah sampah. Intensi dan persepsi partisipan terhadap program pemilahan sampah tidak berpengaruh signifikan terhadap perilaku memilah sehingga meniadakan peran sikap dan norma subjektif dalam perilaku memilah sampah. Hipotesis yang peneliti ajukan ternyata tidak terbukti karena (1) hanya sikap dan norma subjektif yang berkontribusi signifikan terhadap intensi dan (2) hanya perceived behavioral control yang signifikan berkontribusi terhadap perilaku memilah sampah.

Tabel 5. Analisis Regresi terhadap Intensi Memilah Sampah

\begin{tabular}{lcrl}
\hline & B & SE B & $\beta$ \\
\hline Konstan & 9,940 & 3,426 & \\
Sikap & $-0,239$ & 0,107 & $-0,242^{*}$ \\
Norma subjektif & 0,224 & 0,077 & $0,333^{* *}$ \\
Perceived Behavioral Control & 0,007 & 0,115 & $-0,008$ \\
Kepuasan terhadap fasilitas & 0,15 & 0,118 & 0,145 \\
\hline
\end{tabular}

Catatan: *signifikan pada level of confidence 95\%;

** signifikan pada level of confidence $99 \%$ 
Tabel 6. Analisis Regresi terhadap Perilaku Memilah Sampah

\begin{tabular}{|c|c|c|c|}
\hline & B & SE B & $\beta$ \\
\hline Konstan & 4,255 & 2,277 & \\
\hline $\begin{array}{l}\text { Intensi Memilah } \\
\text { sampah }\end{array}$ & 0,021 & 0,081 & 0,026 \\
\hline $\begin{array}{l}\text { Perceived } \\
\text { Behavioral Control }\end{array}$ & 0,332 & 0,078 & $0,456^{* *}$ \\
\hline $\begin{array}{l}\text { Persepsi terhadap } \\
\text { program pemilahan } \\
\text { sampah }\end{array}$ & $-0,010$ & 0,089 & $-0,120$ \\
\hline
\end{tabular}

Catatan: **signifikan pada level of confidence $99 \%$

\section{Diskusi}

Dari hasil temuan di atas, dapat disimpulkan bahwa H1 dan H2 ditolak. Karena hanya sikap dan norma subjektif yang memprediksi perilaku memilah sampah serta hanya PBC yang memprediksi perilaku memilah sampah. Hal ini berbeda dengan penelitian sebelumnya (lihat Greaves, dkk.,2013; Mannetti ,dkk., 2004; Stoeva \& Alriksson, 2017) dimana masingmasing variabel TPB mempunyai kontribusi terhadap intensi dan perilaku memilah

Dari studi kualitatif ditemukan bahwa pengetahuan penjual kantin Universitas XYZ terhadap perilaku memilah sudah cukup baik. Selain itu, ditemukan juga bahwa memilah sampah juga biasa dilakukan oleh penjual kantin Universitas XYZ. Penulis juga menemukan adanya aspek-aspek yang teridentifikasi dalam variabel sikap, norma subjektif dan PBC dalam memengaruhi perilaku memilah. Ditemukan adanya ketiga variabel ini sesuai dengan penelitian sebelumnya (lihat Carr , dkk., 2017; Tan , dkk., 2016) yang juga menemukan adanya ketiga variabel ini di konteks yang berbeda.

Manfaat dari perilaku yang dilakukan merupakan dari variabel sikap (Carr , dkk., 2017) yang ditunjukkan dengan penjual kantin mengetahui manfaat perilaku memilah yang baik untuk lingkungan. Selain itu perilaku memilah sampah juga menimbulkan perasaan yang positif karena menjalankan program wajib universitas dan juga membantu cleaning service. Perasaan positif yang dirasakan individu merupakan aspek dari variabel sikap (Aarts, Verplanken, \& Van Knippenberg, 1998; Tan , dkk., 2016).

Temuan unik dari studi kualitatif ini adalah pentingnya peran cleaning service dalam mengingatkan penjual kantin Universitas XYZ ketika mereka masih melakukan kesalahan dalam pemilahan. Selain itu, penjual kantin juga merasa pemilahan sampah merupakan hal yang penting, terutama ketika figur otoritatif di Fakultas seperti Dekan dan Wakil Dekan memberikan contoh langsung dalam memilah. Sesuai dengan penelitian sebelumnya, teman juga mempunyai peran yang kuat dalam memengaruhi perilaku (Renzi \& Klobas, 2008;
Tan, dkk., 2016) sehingga perilaku rekan sesama pedagang juga memengaruhi norma subjektif individu.

Variabel PBC yang ditemukan adalah persepsi bahwa memilah sampah adalah hal yang mudah dilakukan. Fasilitas akan pemilahan sampah merupakan hal yang dapat memengaruhi persepsi individu terkait kemudahan dalam memilah sampah (Stoeva \& Alriksson, 2017; Tan , dkk., 2016; Zhang, dkk 2016). Individu juga merasa makin mudah memilah saat dibekali pengetahuan tentang bagaimana memilah sampah dan hal ini sesuai dengan temuan dari (Tan , dkk., 2016)

Berbeda dengan temuan kualitatif, studi kuantitatif yang dilakukan hanya dapat membuktikan kontribusi sikap dan norma subjektif dalam memprediksi intensi serta hanya PBC yang memprediksi perilaku memilah sampah. Hal ini berbeda dengan penelitian sebelumnya (Greaves , dkk., 2013; Mannetti, dkk., 2004; Niaura, 2013; Stoeva \& Alriksson, 2017; Tonglet, dkk., 2004; Zhang dkk 2016). Pada temuan kuantitatif sikap berpengaruh secara negatif terhadap intensi yang berarti semakin positif sikap seseorang terhadap pemilahan sampah semakin berkurang intensinya untuk membuang sampah. Hal ini bisa terjadi karena bagi partisipan membuang sampah sudah menjadi hal yang otomatis dilakukan dan tidak bergantung pada intensi. Namun norma subjektif mempunyai pengaruh yang positif dan ini sejalan dengan temuan kualitatif dan juga penelitian sebelumnya (lihat Niaura, 2013; Renzi \& Klobas, 2008; Stoeva \& Alriksson, 2017; Tan , dkk., 2016).

Dalam penelitian ini ditemukan hanya PBC yang signifikan dalam memengaruhi perilaku memilah sampah. Temuan ini mendukung temuan penelitian sebelumnya (lihat Botetzagias , dkk., 2015; Knussen, dkk., 2004; Mannetti, dkk 2004) yang menekankan pada pentingnya PBC dalam memengaruhi perilaku memilah sampah. Hal ini diduga dikarenakan perilaku memilah sampah telah menjadi kebiasaan (habit) di kalangan penjual kantin Universitas XYZ. Sepeti yang dijelaskan oleh Ajzen (2006), semakin sering perilaku dilakukan, maka perilaku tersebut akan berada dalam kendali stimulus eksternal dan meniadakan peran dari intensi. Artinya perilaku pemilahan sampah akan dilakukan secara otomatis ketika ada tanda dari eksternal seperti fasilitas pemilahan sampah. Conner dan Armitage (1998) menyatakan bahwa pada perilaku yang sifatnya telah menjadi kebiasaan, TPB mempunyai peran kecil dalam memprediksikan perilaku. Ketika perilaku menjadi kebiasaan atau secara otomatis dilakukan, intensi secara sadar akan semakin berkurang (Aarts , dkk., 1998).

Aarts , dkk. (1998) juga menyatakan kebiasaan dapat menjadi sumber informasi bagi pedagang kantin Universitas XYZ bahwa dia mampu melakukan perilaku selanjutnya. Kebiasaan juga dapat memengaruhi PBC karena pengulangan dari perilaku akan memengaruhi peningkatan persepsi akan kemampuan pengendalian atau kontrol terhadap perilaku tersebut. Penjelasan dari Aarts, dkk. (1998) dan Ajzen (1991) ini dapat menjelaskan mengapa dalam studi 2 
hubungan antara intensi dengan perilaku memilah tidak signifikan. Temuan ini membuat pengukuran kebiasaan sangat penting dimasukkan ke dalam model TPB extended.

Cara pengukuran intensi penulis ambil dari Zhang, dkk. (2016) juga digunakan oleh Stoeva dan Alriksson (2017). Pengukuran intensi yang peneliti gunakan adalah dengan mengukur kesediaan atau niat untuk memilah sampah dalam rentang waktu hari ini, bulan depan dan dalam tiga bulan ke depan sedangkan perilaku memilah sampah yang peneliti ukur adalah perilaku memilah saat ini (contoh: saya biasanya memisahkan sampah yang bisa didaur ulang). Berdasarkan pernyataan, dapat dilihat bahwa intensi dan perilaku memilah berada pada kontinum waktu yang berbeda. Berbeda dengan hasil penelitian Stoeva dan Alriksson (2017) serta Zhang, dkk (2016), perbedaan intensi yang diukur dalam kontinum waktu yang berbeda saja memengaruhi respon jawaban responden dalam menjawab intensi.

Beberapa responden menanyakan kepada peneliti bahwa dia memang sudah terbiasa memilah sampah sehari-hari apakah harus menjawab pada kontinum setuju di pernyataan berniat memilah di minggu dan bulan depan karena menurut mereka, perilaku mereka sudah terejawantahkah dalam perilaku nyata, bukan hanya sekedar niat. Peneliti mencoba menganalisa lebih jauh dengan me-running skor rata-rata di tiap item intensi dan diperoleh skor ratarata tertinggi ada pada item "Setiap kali membuang sampah, saya akan memilah sampah dengan benar sesuai kategorinya" (M=5,09) dibandingkan item "Saya berniat untuk memilah sampah saya mulai bulan depan" $(M=3,61)$ dan item "Saya benar-benar bersedia untuk memilah sampah saya dengan benar dalam tiga bulan ke depan" $(M=4,22)$. Nampaknya, bagi pedagang kantin universitas XYZ, pertanyaanpertanyaan tentang intensi dianggap tidak relevan karena mereka berpikir bahwa mereka sudah lebih jauh dari hanya berniat. Itu sebabnya tidak ditemukan kontribusi antara intensi dengan perilaku memilah. Untuk penelitian selanjutnya, cara pengukuran intensi yang tepat perlu dipikirkan kembali.

Kepuasan terhadap fasilitas pemilahan sampah juga tidak berhubungan signifikan dengan perilaku memilah sampah. Berbeda dengan temuan Stoeva dan Alriksson (2017), kepuasan terhadap fasilitas memilah tidak memengaruhi perilaku memilah. Hal ini juga dapat dijelaskan dengan kebiasaan tadi dimana saat sudah menjadi perilaku yang otomatis dilakukan, puas atau tidaknya individu terhadap fasilitas pemilahan tidak akan memengaruhi perilaku memilah

\section{Kesimpulan}

Dari hasil penelitian di atas dapat disimpulkan bahwa penjual kantin Universitas XYZ telah mempunyai pengetahuan mengenai program pemilahan sampah di Universitas XYZ. Selain itu, ditemukan juga bahwa perilaku memilah sampah sudah biasa dilakukan oleh penjual kantin Universitas XYZ. Dari hasil kualitatif ditemukan juga adanya ketiga variabel TPB dalam memengaruhi pemilahan sampah. Variabel sikap dibangun dari evaluasi yang berdasarkan pada kewajiban memilah sampah karena adanya program yang berlaku.

Selain itu, evaluasi individu yang menganggap perilaku memilah sampah merupakan hal yang baik dilakukan untuk lingkungan dan adanya rasa tidak enak terhadap CS juga memengaruhi sikap individu terhadap pemilahan sampah. Dalam norma subjektif, kehadiran cleaning service, penjual lain dan pihak yang dianggap otoritatif membuat individu merasa memilah sampah merupakan sesuatu yang wajib dilakukan. Untuk PBC, persepsi akan kemudahan memilah sampah membuat penjual kantin tetap melakukan pemilahan. Hal ini juga didukung oleh adanya fasilitas dan sosialisasi mengenai bagaimana cara memilah.

Dari hasil temuan kuantitatif, penulis hanya dapat membuktikan peran dari Norma subjektif dan sikap dalam memprediksi intensi serta PBC dalam memprediksi perilaku memilah sampah. Dari penelitian studi kualitatif dan kuantitatif peneliti menemukan bahwa perilaku memilah sampah sudah menjadi kebiasaan bagi penjual kantin Universitas XYZ sehingga intensi tidak berperan secara signifikan dalam perilaku memilah. Saat menjadi kebiasaan, peran PBC menjadi relevan dalam menjaga perilaku memilah sampah di kalangan penjual kantin Universitas XYZ.

\section{Keterbatasan dan saran.}

Peneliti menyadari bahwa jumlah penjual yang diwawancara relatif sedikit. Hal ini terkait dengan terbatasnya partisipan yang bersedia untuk diwawancara. Ternyata sulit menemukan waktu yang benar-benar kosong untuk melakukan wawancara. Wawancara pada setting field juga membuat proses wawancara kadang terhenti karena partisipan harus melayani pembeli dan hal ini bisa saja menghalangi proses menjawab dari partisipan. Peneliti juga tidak bisa terlalu lama mewawancarai partisipan dikarenakan waktu partisipan yang terbatas untuk melakukan pekerjaannya sehingga probing tidak bisa dilakukan secara mendalam. Untuk penelitian ke depannya akan lebih baik ketika diatur waktu pada hari libur untuk mewawancarai penjual sesuai dengan kesediaannya.

Penelitian mendatang juga harus mempertimbangkan penggunaan alat ukur intensi yang lebih mudah dipahami oleh pedagang dan sesuai dengan keadaan di lapangan yang mereka alami. Penggalian ketepatan respons secara kualitatif dapat terlebih dahulu dilakukan dalam mengonstruk alat ukur TPB yang cocok dengan kondisi masyarakat Indonesia. Penelitian yang melibatkan partisipan pedagang makanan perlu dilanjutkan, karena untuk mengefektifkan pemilahan sampah maka perlu melibatkan semua pe- 
mangku kepentingan, namun masih sedikit penelitian yang melibatkan mereka.

\section{Daftar Pustaka}

Aarts, H., Verplanken, B., \& Knippenberg, A. (1998). Predicting behavior from actions in the past: Repeated decision making or a matter of habit? Journal of Applied Social Psychology, 28(15), 1355-1374. doi:10.1111/j.15591816.1998.tb01681.x

Ajzen, I. (1991). The Theory of Planned Behavior. Organizational behavior and human decision Processes, 50 (2), 179-211. doi:10.1016/07495978(91)90020-T

Ajzen, I. (2006). Behavioral interventions based on the theory of planned behavior. Organizational Behavior and Human Decision Processes, 50(2), 179-211. doi:10.1016/0749-5978(91)90020$\mathrm{T}$

Ajzen, I. (2011a). Constructing a theory of planned behavior questionnaire.

Ajzen, I. (2011b). The theory of planned behaviour: Reactions and reflections. Psychology and Health, 26(9), 1113-1127. doi:10.1080/08870446.2011.613995

Ajzen, I., \& Fishbein, M. (1972). Attitudes and normative beliefs as factors influencing behavioral intentions. Journal of Personality and Social Psychology, 21(1), 1-9. doi;10.1037/h0031930

Conner, M., \& Armitage, C. J. (1998). Extending the theory of planned behavior: A review and avenues for further research. Journal of Applied Social Psychology, 28(15), 1429-1464. doi:10.1111/j.1559-1816.1998.tb01685.x.

Botetzagias, I., Dima, A. F., \& Malesios, C. (2015). Extending the theory of planned behavior in the context of recycling: The role of moral norms and of demographic predictors. Resources, Conservation and Recycling, 95, 5867. doi:10.1016/j.resconrec.2014.12.004

Carr, A., Shin, Y. H., Severt, K., \& Lewis, M. (2017). A qualitative approach to understand the underlying beliefs of microbrewery consumers. International Journal of Hospitality Beverage Management, 1(1). Diunduh dari https://scholars.unh.edu/cgi/viewcontent.cgi ?referer=https://www.google.com/\&httpsred ir $=1 \&$ article $=1006 \&$ context $=\mathrm{ijhbm}$

Creswell, J. W. (2007). Qualitative Inquiry and Research Design: Choosing Among Five Approaches.pdf (2nd edition). California: Sage Publication. doi:10.1111/1467-9299.00177

Fan, B., Yang, W., \& Shen, X. (2019). A comparison study of 'motivation-intention-behavior' model on household solid waste sorting in China and Singapore. Journal of Cleaner Production, 211, 442-454.
Greaves, M., Zibarras, L. D., \& Stride, C. (2013). Using the theory of planned behavior to explore environmental behavioral intentions in the workplace. Journal of Environmental Psychology, 34 , 109-120. doi;10.1016/j.jenvp.2013.02.003

Universitas Indonesia. (2018). Petunjuk UI GreenMetric World University Rankings 2018 (2nd editio). Depok: University of Indonesia. doi:10.1016/s0921-4534(99)00502-x

Kaplan, R. M., \& Sacuzzo, D. P. (2009). Psychological Testing: Principles, Applications, \& Issues (7th ed.). Belmont: Wadsworth Cengage Learning.

Klobas, J. (2011). The Theory of planned behaviour as a model of reasoning about fertility decisions. Vienna Yearbook of Population Research, 9, 4754. doi:10.1553/populationyearbook2011s47

Knussen, C., Yule, F., MacKenzie, J., \& Wells, M. (2004). An analysis of intentions to recycle household waste: The roles of past behaviour, perceived habit, and perceived lack of facilities. Journal of Environmental Psychology, 24(2), 237-246. doi:10.1016/j.jenvp.2003.12.001

Kumar, R. (2018). Research methodology: A step-bystep guide for beginners. doi:10.22201/iibi.0187358xp.1999.27.3925

Mannetti, L., Pierro, A., \& Livi, S. (2004). Recycling: Planned and self-expressive behaviour. Journal of Environmental Psychology, 24(2), 227-236. doi:10.1016/j.jenvp.2004.01.002

Miliute-Plepiene, J., Hage, O., Plepys, A., \& Reipas, A. (2016). What motivates households recycling behaviour in recycling schemes of different maturity? Lessons from Lithuania and Sweden. Resources, Conservation and Recycling, 113, 4052. doi:10.1016/j.resconrec.2016.05.008

Mulya. (2018, 28 November). Komunikasi Personal

Niaura, A. (2013). Using the theory of planned behavior to investigate the determinants of environmental behavior among youth. Environmental Research, Engineering and Management, 63(1), 74-81. doi:10.5755/j01.erem.63.1.2901

Renzi, S., \& Klobas, J. (2008). Using the Theory of Planned Behavior with Qualitative Research. In Dondena Working Paper Milan, Italy..

Stoeva, K., \& Alriksson, S. (2017). Influence of recycling programmes on waste separation behaviour. Waste Management, 68, 732-741. doi:10.1016/j.wasman.2017.06.005

Tan, C. L. H., Hassali, M. A., Saleem, F., Shafie, A. A., Aljadhay, H., \& Gan, V. B. Y. (2016). Building intentions with the theory of planned behaviour: a qualitative assessment of salient beliefs about pharmacy value added services in Malaysia. Health Expectations, 19(6), 12151225. doi;10.1111/hex.12416

Tarmuji. (2018, 22 November). Komunikasi Personal. Tonglet, M., Phillips, P. S., \& Bates, M. P. (2004). Determining the drivers for householder proenvironmental behaviour: Waste minimisation compared to recycling. Resources, Conservation 
and Recycling, 42(1), 27-48. doi:10.1016/j.resconrec.2004.02.001

Universitas Indonesia. (2018). Laporan Hasil Monitoring dan Evaluasi Pengelolaan Sampah Universitas Indonesia Semester I Tahun 2018. Depok: UI

Urbina, S. (2004). Essentials of Psychological Testing. (A. S. Kaufman \& N. L. Kaufman, Eds.). Danvers: John Wiley \& Sons, Inc.

Welcomer, S., Scherer, R. F., Pradenas, L., Cordano, M., \& Parada, V. (2010). A cross-cultural assessment of three theories of pro-environmental behavior. Environment and Behavior, 43(5), 634-657. doi:10.1177/0013916510378528

Willig, C. (2008). Introducing Qualitative Research in Psychology. McGraw Hill (2nd Edition). Glasgow: Mc Graw Hill.

Zhang, S., Zhang, M., Yu, X., \& Ren, H. (2016). What keeps Chinese from recycling: Accessibility of recycling facilities and the behavior. Resources, Conservation and Recycling, 109, 176-186. doi:10.1016/j.resconrec.2016.02.00 